\title{
A MODEL FOR INCORPORATING SPECIALIST NURSE EDUCATION INTO A UNIVERSITY CONTEXT. Part 1: Methodological perspectives
}

\author{
Authors: \\ Judith C. Bruce ${ }^{1}$ \\ Hester C. Klopper ${ }^{2}$ \\ Affiliations: \\ ${ }^{1}$ Department of Nursing \\ Education, University \\ of Witwatersrand, \\ South Africa \\ ${ }^{2}$ School of Nursing \\ Science, North-West \\ University, Potchefstroom \\ campus, South Africa
}

Correspondence to:
Judith Bruce

email:

judith.bruce@wits.ac.za

\section{Postal address:}

Department of Nursing

Education, Wits Medical

School, 7 York Road,

Parktown, Johannesburg

2193, South Africa

\section{Keywords:}

specialist nurse education; tertiary education; methodological perspectives; theory generation; relational statements

\section{Dates:}

Received: 01 Sept. 2009

Accepted: 15 Sept. 2009

Published: 30 Mar. 2010

\section{How to cite this article:} Bruce, J.C. \& Klopper, H.C., 2010, 'A model for incorporating specialist nurse education into a university context. Part 1: Methodological perspectives', Health $S A$ Gesondheid 15(1), Art \#494, 6 pages. DOI: $10.4102 /$ hsag.v15i1.494

This article is available at: http://www.hsag.co.za

(C) 2010. The Authors. Licensee: OpenJournals Publishing. This work is licensed under the Creative Commons Attribution License.

\section{ABSTRACT}

The education of nurses for specialist practice takes place mainly in nursing colleges. In view of ongoing debates about the future positioning of nursing education, an investigation regarding the incorporation of college-based specialist nurse education into universities was needed. The purpose of the study was to develop and describe a model for specialist nurse education in a university. The objectives were set in two phases: Phase 1 objectives were designed to enable the identification of concepts in relation to university education and Phase 2 objectives, to enable the development of a model for specialist nurse education in a university context. This paper gives an account of only the methodology used to meet the research purpose and objectives. It outlines the objectives of Phases 1 and 2, including a detailed description of the research design. In discussing the research design, particular attention was given to theory development. The research methods were described with reference to data collection methods and procedures, study samples and sampling methods, data analysis methods and processes, to ensure the trustworthiness of the study. The model is described in Part 2 of the article.

\section{OPSOMMING}

Die onderrig van verpleegkundiges in gespesialiseerde verpleegpraktyk vind hoofsaaklik in verpleegkolleges plaas. In die lig van die voortslepende debat rondom die toekomstige posisionering van verpleegonderrig is ondersoek na die inkorporering van spesialis vepleegopleiding aan universitieite as noodsaaklik geag. Die doel van hierdie studie was om die model vir gespesialiseerde vepleegopleiding aan universitiete te ontwikkel en te beskryf. Die navorsingsdoelwitte is geformuleer aan die hand van twee fases. Die doelwitte in Fase 1 was ontwerp om die konsepte betreffende universiteitsopleiding te identifiseer. Die doelwitte in Fase 2 was op die ontwikkeling van 'n model vir die onderrig in gespesialiseerde verpleegkunde aan ' $n$ universiteit gerig. Hierdie artikel gee 'n oorsig oor slegs die metodiek wat gebruik is om die doel en navorsingsdoelwitte te bereik. Dit verskaf 'n oorsig oor Fase 1 en 2 en sluit 'n omvattende beskrywing van die navorsingsontwerp in. In die bespreking van die navorsingsontwerp word spesifieke aandag aan teoriegenerering gewy. Die navorsingsmetodes word beskryf met verwysing na data insamelingsmetodes-en-prosedures, die steekproef, en steekproefmetodes, data analiseringsmetodes-en-prosedures wat die betroubaarheid van die studie verseker het. Die model word in Deel 2 van die artikel beskryf.

\section{INTRODUCTION}

\section{Background}

Internationally, nursing education for generalist and specialist practice has gained higher education status in such countries as Australia, Canada, the USA and the UK. The move of nursing education into universities as part of higher education necessitated the adoption of a new approach to nurse education, which generally has had positive outcomes for the profession and nursing care in the said countries over the last 10 years, particularly in specialist nurse education. Some outcomes here include better decision-making skills, greater professional autonomy and an ongoing quest for knowledge (Traynor \& Rafferty 1999:85). Despite successful global examples, the issue of university education for professional nurses has eluded the South African nursing profession for many years. Although nursing colleges are not designated higher education institutions per se, higher education status is conferred upon them by way of a legal agreement between universities and provincial health departments on behalf of nursing colleges. Though agreements have been in existence for several years, it is only current legislation that requires nursing colleges to consider making the transition into the higher education sector. This has been prompted mainly through the repeal of laws previously governing higher education and the replacement of such laws by the Higher Education Act (Act No. 101 of 1997, as amended) and the Higher Education Amendment Act of 2008. The latter defines higher education as 'all learning programmes leading to a qualification that meets the requirements of the Higher Education Qualifications Framework (HEQF)'. By virtue of such a definition, college-based basic and post-basic (specialist) nursing programmes are not considered as a form of higher education. The Act (Act No. 101 of 1997) further defines the new higher education sector as comprising universities and technikons (universities of technology), requiring all colleges to redefine their position in relation to the provision. It can be argued that, if nursing colleges are not legally recognised as part of the higher education establishment, in terms of their wanting to continue to offer learning programmes, their incorporation into the transformed higher education sector, or their establishment as autonomous higher education institutions, becomes mandatory.

Additionally, as a result of the provincial policy on the rationalisation of nursing colleges in 1996, the institution under study was assigned the oversight responsibility for college-based specialist nurse education in the Johannesburg region. In the light of this responsibility and within the context of current legislation, it is essential to determine how college-based specialist nursing education can be 
restructured and incorporated into a university. Although the entire nursing education system needs to be considered, this research was bound to the context of exploring college-based specialist nurse education only.

\section{PROBLEM STATEMENT}

Changing from college-based to university education challenges the philosophical underpinnings of educational approaches used for preparing specialist nurses. On the one hand, in regards to university education, college preparation focuses on the transmission of a unidisciplinary knowledge base and on the application of knowledge to vocation-based practice. There is limited evidence in nursing colleges of the traditional scientific model espoused by universities. On the other hand, the professional values of caring and competence, as embodied in the traditions of nursing, remain somewhat contested in university education (Edwards \& Knight 1995:23; Watson 2002:476). In the same vein, contemporary universities are challenged to embrace these values in their quest to become more socially responsive. It seems apparent that values and traditions are challenged in both educational contexts, and that an alternative approach is needed for the education of collegebased specialist nurses, which protects the traditions of the discipline, and which, simultaneously, optimises the scientific contexts for research, theory and practice development accorded by university education.

In view of ongoing debates about the future positioning of college-based nursing education, an investigation regarding the incorporation of specialist nurse education into universities was needed. The views of specialists, namely nurse educators and practitioners, are central to providing an emic perspective on incorporation into a university context. In relation to this, the following research questions were posed:

- What are the concepts and related concepts in specialist nurse education in the context of a university?

- What are the relationships between these concepts and how might these relationships be constructed for the systematic development of a model for specialist nurse education?

\section{RESEARCH OBJECTIVE}

The purpose of this study was to develop and describe a model for incorporating specialist nurse education into a university. In order to achieve such a purpose, the research objectives were set in two phases. Phase 1 objectives were designed to enable the identification of concepts in relation to university education for specialist nurses, whereas Phase 2 objectives were designed to enable the development of a model for specialist nurse education in a university context. This paper focuses on the methodology for the attainment of the objectives in Phase 1 through to the attainment of those in Phase 2.

\section{Objectives of Phase 1}

The objectives of Phase 1 of the study were:

- To explore and describe the factors and events that influenced the need for, and the development of, specialist courses for nurses.

- To explore and describe the views of specialist nurse educators, who work at nursing colleges, in relation to specialist nurse education provided by a university.

- To explore and describe the views of specialist nurse practitioners, who work at academic hospitals, in relation to specialist nurse education provided by a university.

\section{Objectives of Phase 2}

The objectives of Phase 2 of the study were:

- To identify and describe the concepts in the model for specialist nurse education in a university context.
- To construct relational statements between concepts in specialist nurse education.

\section{CONCEPT CLARIFICATION}

In the context of this study, the following applies:

- The term 'specialist nurse education' refers to the teaching and learning programmes that are offered to registered nurses who are enrolled at a public-sector nursing college for the registration of an additional qualification, in terms of South African Nursing Council (SANC) Regulation No. 212 of 1993. Such programmes are also referred to as post-basic programmes.

- The term 'specialist nurse educator' refers to a nurse who is registered with the SANC as a nurse educator and who holds an additional qualification in, and teaches, a medicalsurgical nursing field, in terms of SANC Regulation No. 212 of 1993.

- The term 'specialist nurse practitioner' refers to a registered nurse who holds an additional qualification in a medicalsurgical field, in terms of SANC Regulation No. 212 of 1993, and who practices in that field in an academic hospital.

- The term 'nursing college' refers to a nursing education institution of the Gauteng Department of Health, which is accredited by SANC to offer nursing programmes, in association with a university.

\section{RESEARCH DESIGN}

The qualitative paradigm was chosen as an overarching approach to the design of the study, which was theory generative, exploratory, descriptive and contextual. Understanding the basic assumptions underlying a qualitative approach provided the researchers with a profound sense of direction regarding the design of the phases of the study. Justifications for using the characteristic designs are provided below.

\section{Theory generative design}

A theory is generally described as being an integrated set of defined concepts, existence statements and relational statements, which present a certain view of a phenomenon (Burns \& Grove 2005:142). In the context of qualitative research, data are examined for patterns and relationships between phenomena, with hypotheses and theories emerging from the data. A qualitative approach to nursing theory is, therefore, based on inductive reasoning and embodies principles that explain, describe, predict or control the phenomena being investigated. The data obtained from the exploration of the views of the key informants, the specialist nurse educators and the specialist nurse practitioners, are examined for patterns and relationships and ultimately contribute to the model that incorporates specialist nurse education into a university context. In this study, the development of a model is regarded as being consistent with middle-range theory generation (George 2002:6), which, in turn, guides the education practice of specialist nurses. According to Smith and Liehr,

[m] iddle range theory can be defined as a set of related ideas that are focused on a limited dimension of the reality of nursing. These theories are composed of concepts and suggested relationships among the concepts that can be depicted in a model. Middle range theories are developed and grow at the intersection of practice and research to provide guidance for everyday practice and scholarly research rooted in the discipline of nursing. We use the ladder of abstraction to articulate the logic of middle range theory as related to a philosophical perspective and practice/research approaches congruent with theory conceptualization.

(2008:xvii)

\section{Elements of theory generation}

Concepts and statements are integral to theories and, as such, theory development often begins with these basic elements. 
TABLE 1

A comparison of processes for theory/model development

\begin{tabular}{llll}
\hline & Walker \& Avant (1995) & Chinn \& Kramer (1991) & Processes used in this study \\
\hline Concept development & Concept analysis, synthesis and derivation & $\begin{array}{l}\text { Creating conceptual meaning } \\
\text { Structuring and contextualising theory }\end{array}$ & $\begin{array}{l}\text { Concept synthesis } \\
\text { Rationale: to develop concepts based on } \\
\text { empirical evidence i.e. interview data }\end{array}$ \\
Statement development & Statement analysis, synthesis and derivation & Generating and testing theoretical relationships & $\begin{array}{l}\text { Statement synthesis } \\
\text { Rationale: to specify relationships between } \\
\text { concepts developed }\end{array}$ \\
Theory development & Theory analysis, synthesis and derivation & Deliberate application of theory & $\begin{array}{l}\text { Theory synthesis } \\
\text { Rationale: to express new insights into the } \\
\text { phenomenon }\end{array}$ \\
\hline
\end{tabular}

Beginning the process of theory development requires creative and rigorous structuring of concepts, which, in turn, are conveyed as relationship statements. Creating conceptual meaning is thus the basis of theory development, which, in the end, presents a systematic view of the phenomena being explored. In this study, the phenomenon of specialist nurse education was explored within a university context, with the end result being systematic model development. Table 1 depicts a comparison of the processes for model development, including those that guided model development in this study.

\section{Exploratory design}

Exploration enables the researcher to gain a richer understanding of, and insight into, a relatively new phenomenon, for which little or no research has been done (McMillan \& Schumacher 2006:318). Within the context of this research, exploration was used to gain insight into the views of participants (specialist nurse educators and practitioners) regarding university education for college-based specialist nurses (Bruce \& Klopper 2008:5-20). Additionally, the incorporation of college-based programmes into a university is a relatively new phenomenon for nursing education in South Africa, requiring exploration. Therefore, it was appropriate to use an exploratory design to meet the study purpose.

\section{Descriptive design}

Description implies an accurate account of the phenomena being studied. It requires, and is preceded by, appropriate and complete data collection. In this study, such description involved the collection of qualitative data by means of focus group interviews with specialist nurse educator and practitioner groups, which were transcribed verbatim. By way of themes and sub-themes that emerged from the interview transcripts, a descriptive approach was used to give an account of the participants' views regarding specialist nurse education, as well as of the concepts and ultimately, the model for incorporating specialist nurse education into a university.

\section{Contextual design}

A context is characterised by a 'specific set of properties pertaining to a phenomenon and a particular set of circumstances', within which an action takes place (Strauss \& Corbin 1990:101). Such a set serves to define and describe the setting within which research actions occur and, as such, is only valid within certain dimensions such as those relating to time and space, or to culture. The study context was determined by the Gauteng provincial policy for nursing education and the national education policy for higher education. The study was delimited to the Gauteng province. Although the entire nursing education system requires consideration, the current research was bound to the context of exploring specialist nurse education alone.

\section{RESEARCH METHOD}

The methodological perspectives of the study, with reference to concept identification and development and statement development, are explained and justified in this article. The participant samples and sampling methods, data collection techniques and procedures, data analysis and measures of trustworthiness are described here as well. Such methodological perspectives and ethical considerations are integrated into the discussion of the empirical data that were collected during the study's two phases and sub-phases, each of which articulates with the objectives of the study.

\section{Phase 1: Concept identification}

The purpose of concept identification is to formulate conceptual ideas, which is the first step towards establishing a conceptual framework. To initiate the identification of concepts, two methods of data collection were used, namely individual and focus group interviews. Individual interviews were conducted with the key informants representing the regulatory body, the university sector and a provincial health department, in order to generate data in relation to the first study objective (1a), which was to explore and describe the factors and the events that influenced the need for, and the development of, specialist courses for nurses. Objectives 1(b) and 1(c) were accomplished by conducting focus-group interviews with specialist nurse educators at the nursing colleges and with specialist nurse practitioners at the academic hospitals. The methodological perspectives on data collection for concept identification are discussed below.

\section{Data collection}

Individual and focus-group interviews: Non-probability, purposive sampling was used to select key informants $(n=3)$ for individual interviews, in order to generate developmental data specific to specialist nurse education. Non-probability sampling methods raise concerns around bias, representivity and, hence, generalisation ability. The choice of such a sampling method, however, was consistent with the exploratory nature of the study, which Burns and Grove (2005:374) view as 'not intended for generalizations to large populations'. An interview guide was used to explore four focal questions. Although the purpose of the questions was to guide the interview, the questions were used flexibly to allow for the probing into, and exploration of, responses.

The interviews of four focus groups were conducted with purposively sampled nurse educator $(n=17)$ and specialist nurse practitioner groups $(n=13)$, to explore their views in relation to specialist nurse education in a university context. The rationale for using focus groups lay in the ability of this method to explore a new and potentially complex phenomenon through interaction and the exchange of ideas, which does not happen in individual interviews. Generally, three or more focus groups are proposed if participants have diverse exposure to the topic, when participants are heterogeneous, or when national insights are needed into the topic. The homogeneous nature of the groups in respect of gender, educational qualifications, rank, campus (geographic) location and level of specialist course involvement, afforded the participants focused exposure to the topic. As a result of the relative homogeneity of the sample, the theoretical saturation of data categories (Krueger 1994:89; Strauss \& Corbin 1990:188) was quickly reached and, as such, 
justified the use of two focus groups, namely those of specialist nurse educators and specialist nurse practitioners, in each target group. Four focus-group interviews were conducted in all. The nurse educator group participants $(n=7 ; n=10)$ were all female, aged between 23 and 49 years and the specialist nurse practitioner group participants $(n=6 ; n=7)$ were aged between 28 and 48 years.

\section{Analysis of interview data}

Data from individual interviews and focus-group interviews were transcribed and, on completion, were carefully read through. The plan for data analysis included simultaneous data interpretation and narrative report writing.

The process of data analysis involved data 'reduction' and 'interpretation', which allows the data to be reduced into themes for interpretation by using a 'schema' (Creswell 1994:154). As the interview data were semi-structured, Tesch's 8-step coding procedure was adapted from that of Creswell (1994:154) and was used as a guide for analysing the transcribed text. No recoding of data, as enumerated in the final step of Tesch's guidelines, was indicated; therefore, a 7-step procedure was followed.

The coding procedure began by reading each transcript carefully, in order to gain an overall view of what had been said. It was important, at this stage, not to look for substance or utility in the information, because doing so would have partially obscured thr intended meaning of the information. The second step entailed gaining a sense of the underlying meaning, by asking questions such as 'What is this about?' and 'What is she really saying?' Emerging thoughts and comments were written in the margin of the transcribed text. The list was reduced to groups of similar topics, which were coded using colour highlights. In the next step, it was necessary to return to the data, in order to colour code the appropriate segments of the transcript (Creswell 1994:155). Appropriate descriptive words were used to translate the coded topics into six themes for the individual interviews, and into five and four themes for each of the two focus group categories respectively. Deductive reasoning enabled 14 conclusion statements to be drawn up in relation to the emerging themes and sub-themes.

The data collected during phases 1(a), 1(b) and 1(c) contributed to the attainment of the Phase 2 objectives.

\section{Phase 2: Concept description and relational statements}

As theories comprise concepts, definitions and statements and are graphically represented as theoretical models, it follows that such components require systematic development for the successful establishment of models. The researchers' approach to model development is summarised in Table 2, which is a conceptual extension of Table 1 (see the earlier explanation in this regard).

TABLE 2

Approach to model development

\begin{tabular}{llll}
\hline Element of theory & \multicolumn{2}{c}{ Researchers' approach to model development } \\
\cline { 2 - 4 } & Strategy & Use & Rationale \\
\hline $\begin{array}{l}\text { Concept } \\
\text { development }\end{array}$ & $\begin{array}{l}\text { Concept } \\
\text { synthesis }\end{array}$ & $\begin{array}{l}\text { To identify concepts } \\
\text { based on empirical data }\end{array}$ & $\begin{array}{l}\text { Available concepts } \\
\text { were limited and } \\
\text { generally unexplored }\end{array}$ \\
$\begin{array}{l}\text { Statement } \\
\text { development }\end{array}$ & $\begin{array}{l}\text { Statement } \\
\text { synthesis }\end{array}$ & $\begin{array}{l}\text { To construct relationships } \\
\text { by way of relational } \\
\text { statements between } \\
\text { two or more concepts } \\
\text { eveloped above }\end{array}$ & $\begin{array}{l}\text { Evidence available in } \\
\text { data generated from } \\
\text { individual and group } \\
\text { interviews and from } \\
\text { literature }\end{array}$ \\
$\begin{array}{l}\text { Theory } \\
\text { development }\end{array}$ & $\begin{array}{l}\text { Theory } \\
\text { synthesis }\end{array}$ & $\begin{array}{l}\text { To pull together relational } \\
\text { statements in a coherent } \\
\text { manner to represent the } \\
\text { model for specialist nurse } \\
\text { education }\end{array}$ & $\begin{array}{l}\text { Availability of } \\
\text { systematically } \\
\text { developed relational } \\
\text { statements }\end{array}$ \\
\hline
\end{tabular}

\section{Concept development (description)}

By way of concept synthesis, the concepts in the study, as well as the literature contextualisation of individual interviews and focus-group interviews, were developed (identified and described) from the results. Concept synthesis is a strategy that uses different forms of empirical evidence as a basis for the development of concepts (Walker \& Avant 1995:55). Hence, concept synthesis always begins with raw data, which, in this study, were obtained from the individual interviews and the focus group interviews. This strategy was used to generate new ideas and to examine the data for new insights, which can enhance the development of a theoretical model. Three approaches to concept synthesis are generally referred to the qualitative, quantitative and literary approaches. A literary approach requires the careful review of literature for the purpose of acquiring new insights into phenomena. For the purpose of the current study, the qualitative and literary approaches were found to be suitable. Technical literature, in the form of research, theoretical and philosophical papers having to do with higher education and specialist nursing education, was used for the determination of the approach to, and the interpretation of, data, in order to foster theoretical sensitivity and to validate certain findings.

Main concepts were identified by means of 'searching out' (Chinn \& Kramer 1995:79) words and groups of words that represent the phenomena or events embedded in the conclusion statements $(n=14)$. A total of 29 concepts and related concepts was developed (see Figure 1). Such a development was followed by concept classification (Dickoff, James \& Wiedenbach, 1968:420), which was aimed at the systematic ordering of the concepts and their related concepts.

\section{Statement development}

Statement development was employed in order to advance beyond the concept development stage. A strategy for statement development was carefully selected on the basis of the researcher's judgment of 'the state of the art of existing knowledge' (Walker \& Avant 1995:79) about the research topic. The authors propose three conditions in existing literature that might facilitate a researcher's choice of strategy. In the context of this study, the literature was found to be undeveloped, which was a condition specified by Walker and Avant (1995:80), not research-based and mainly bound by legal prescription. Where such conditions prevail, either statement synthesis or statement derivation are suggested as strategies directed at statement development. The authors further caution against the use of more than one strategy, suggesting the selection and use of only one strategy, until such strategy is no longer of use.

The study employed statement synthesis, which is an empirically based strategy, aimed at specifying relationships between two or more concepts, which are derived from the evidence. The purpose of such synthesis is the development of one or more statements about relationships that exist between the concepts (Walker \& Avant 1995:97). Quantitative and qualitative methods are proposed for making inferences from empirical observations, whereas literary methods are proposed for moving from specific to general inferences. The purpose of literature control in this study operationalised the inductive processes needed for the statement synthesis, during which six statements and 29 relational statements were synthesised.

Based on relational st atements, the processes of statement synthesis and deductive logic led to the structural composition of the model. Part 2 of this paper describes this model.

\section{ETHICAL CONSIDERATIONS}

The study was approved by, and received ethical clearance from, the relevant university committees. Permission to conduct the study was obtained, in writing, from the heads of the 


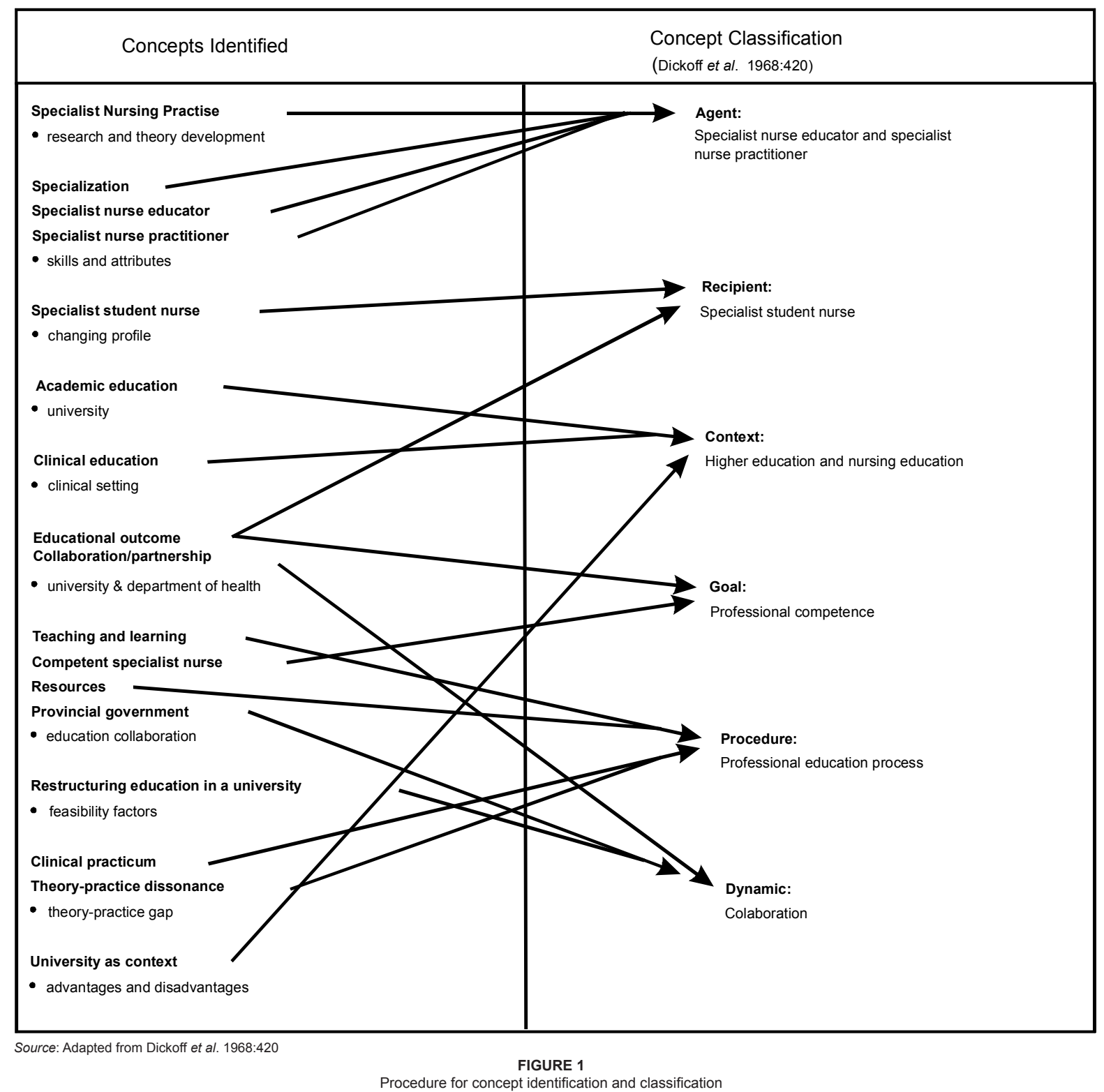

nursing colleges and the academic hospitals concerned. The participants gave their informed verbal consent to taking part in the study, after they had each received a written explanation of the study. Permission to record the data was obtained prior to the interviews, after the purpose behind such audio taping was explained. The recording device in both instances was set up, and in no way interfered with the interview process and the responses of the participants. The researchers conducted the individual and focus- groups interviews.

After issues of confidentiality had been reiterated, anonymity was assured during transcription by assigning numbers to the participants, according to their seating arrangement. The principles of autonomy and fairness were upheld, in that those participants who wished to withdraw from the study could do so during any stage of the data collection. The participants were assured that they would not be coerced to continue and that they would not be disadvantaged in any way by the researcher or the outcomes of the study.

\section{TRUSTWORTHINESS}

The merit of any scientific investigation rests on the basic rules of scientific practice and on basic epistemological standards. In relation to the latter, the merit or trustworthiness of qualitative inquiry (Krefting 1991:215) depends on the truth value, applicability, consistency and neutrality of the research findings concerned. On the basis of such criteria, several strategies for the assessment of the trustworthiness of qualitative research have been proposed (Lincoln \& Guba 1985:301). Such criteria are discussed in relation to the specific strategies that were applied to increase the trustworthiness of the study, and during the collection and analysis of the interview data.

\section{Criteria and strategies directed towards securing trustworthiness}

Threats to the credibility of the study were minimised by means of peer examination of the research proposal by members of the University Ethics and Postgraduate Committees. In particular, the study was assessed for adherence to the principles of good science and human ethics. The research techniques and sampling methods were examined for rigour and procedure.

Although the design is contextual, the transferability of findings might be considered, due to the similarity of governance, financing and the provision of specialist nursing education between the various provinces in the country. 
TABLE 3

Criteria and strategies for trustworthiness: Data collection and analysis

\begin{tabular}{ll}
\hline Criterion & Strategies applied \\
\hline Truth value (credibility) & $\begin{array}{l}\text { Peer examination } \\
\text { Investigator triangulation by independent coder } \\
\text { Member checking } \\
\text { Interview technique }\end{array}$ \\
Applicability (transferability) & $\begin{array}{l}\text { Dense description of informants, research context } \\
\text { and setting }\end{array}$ \\
Consistency (dependability) & $\begin{array}{l}\text { Dense description of research methods } \\
\text { Consensus validation }\end{array}$ \\
Neutrality (confirmability) & $\begin{array}{l}\text { Auditing of raw data (audio recordings), interview } \\
\text { transcripts, Interview categories } \\
\text { Member checking }\end{array}$ \\
\hline
\end{tabular}

Specific strategies directed towards securing trustworthiness were applied during the data collection and analysis (see Table 3). Interviews are generally assumed, by several sources (Reed \& Payton 1997:768; Sandelowski 1993:3), to possess high face validity, due to the credibility of the experiences, views and comments of the participants concerned. In this study, the views

expressed and comments made by participants in focus groups were considered credible. In relation to the issue of credibility, Lincoln and Guba (1985:303) and Krefting (1991:215) refer to the 'truth value' of the informants' perceptions and views and state, further, that adequacy in the researchers' descriptions and interpretations of interview data, namely the interview technique, serves to enhance their credibility.

Two experts in qualitative research, with no vested interest in the research outcomes, reviewed the questions used in this study, as well as potential probes. Although highly contested by qualitative researchers, 'member checking' of the interview transcripts was employed in order to authenticate the data obtained, as well as to ensure the accurate translation of the informants' views. Seven $(n=7)$ and four $(n=4)$ participants, in the nurse educator and specialist nurse practitioner groups respectively, undertook the member checks.

Although the study may be replicated, variations, rather than consistency, might be expected, by virtue of both the researchers' and participants' enhanced insight into, and the possibility of saturation of, the phenomenon under study. Such factors are anticipated to influence the dependability criterion. However, the dependability of the study was enhanced by means of the detailed description of the research methods and the consensus validation undertaken during the data analysis. During the consensus validation, an independent coder was employed to assess the coding consistency and the assigning of the same categories to given units of interview data.

Neutrality was assured by exposing three data sources, namely the raw data, the interview transcripts and the interview categories, to external auditing by an expert qualitative researcher, who also acted as an independent coder. The member checking of interview transcripts was used to confirm the verbatim nature of the interviewees' responses.

\section{CONCLUSION}

University education is posited as a model for the future preparation of college-based nurses for specialist practice. This paper described the research methodology employed to develop a model for incorporating college-based specialist nurse education in the higher education sector via the existing structure of a university. Using an exploratory, theory-generative design, data were collected by means of individual interviews and focus-group interviews conducted with participants who were purposively selected. The process of model development was described, based on a synergogic approach, which included concept, statement and theory synthesis.

The concepts that were identified and developed were used as the basis for constructing relational statements, for collating the information generated regarding university education for specialist nursing practice. The relationships between and within statements are depicted graphically as a theoretical model, which is described in Part 2 of this paper.

\section{REFERENCES}

Bruce, J.C. \& Klopper, H.C., 2008, 'University education for specialist practice: Views of specialist nurse practitioners', Africa Journal of Nursing and Midwifery 10(2), 5-20.

Burns, N. \& Grove, S.K., 2005, The practice of nursing research: Conduct, critique and utilization, WB Saunders, Philadelphia.

Chinn, P. \& Kramer, M., 1995, Theory and nursing: A systematic approach, Mosby, St Louis.

Council on Higher Education (CHE), 2001, 'The state of higher education in South Africa', Annual Report 2000/2001, CHE, Pretoria.

Creswell, J.W., 1994, Research design: Qualitative and quantitative approaches, SAGE, London.

Department of Education, 2001, National Plan for Higher Education, Department of Education, Pretoria.

Dickoff, J., James, P. \& Wiedenbach, E., 1968, 'Theory in a practice discipline. Part 1: Practice oriented theory', Nursing Research 17(5), 415-435.

Edwards, A. \& Knight, P., 1995, Assessing competence in higher education, Kogan Page, London.

George, J.B., 2002, Nursing theories: The base for professional nursing practice, Prentice-Hall International, London.

Krefting, L., 1991, 'Rigor in qualitative research: The assessment of trustworthiness', American Journal of Occupational Therapy 45(3), 214-222.

Krueger, R.A., 1994, Focus groups: A practical guide for applied research, SAGE, Thousand Oaks, CA.

Lincoln, Y.S. \& Guba, E.A., 1985, Naturalistic inquiry, SAGE, Beverly Hills, CA.

McMillan, J.H. \& Schumacher, S., 2006, Research in education evidence-based inquiry, Pearson Education, Boston.

Reed, J. \& Payton, V.R., 1997, 'Focus groups: Issues of analysis and interpretation', Journal of Advanced Nursing 26, 765-771.

Sandelowski, M., 1993, 'Rigor or rigor mortis: The problem of rigor in qualitative research revisited', Advances in Nursing Science 16(2), 1-8.

Smith, M.J. \& Liehr, P.R., 2008, Middle range theory for nursing, 2nd edn., Springer, New York.

South Africa, 1997, Higher Education Act, Government Printer, Pretoria.

South Africa, 2008, Higher Education Amendment Act, Government Printer, Pretoria.

South African Nursing Council (SANC), 1993, Regulations relating to the course in clinical nursing science leading to registration of an additional qualification, R212, SANC, Pretoria.

Strauss, A. \& Corbin, J., 1990, Basics of qualitative research, SAGE, London.

Traynor, M. \& Rafferty, A.M., 1999, 'Nurse education in an international context: The contribution of contingency', International Journal of Nursing Studies 36, 85-91.

Walker, L. \& Avant, K.C., 1995, Strategies for theory construction in nursing, Prentice-Hall International, London.

Watson, R., 2002, 'Clinical competence: Starship enterprise or straitjacket?', Nurse Education Today 22(6), 476-480. 